\title{
Comparative Study of Heavy Metals in Soil and Selected Medicinal Plants
}

\author{
Afzal Shah, ${ }^{1}$ Abdul Niaz, ${ }^{1}$ Nazeef Ullah, ${ }^{1}$ Ali Rehman, ${ }^{2}$ Muhammad Akhlaq, ${ }^{2}$ \\ Muhammad Zakir, ${ }^{2}$ and Muhammad Suleman Khan ${ }^{2}$ \\ ${ }^{1}$ Department of Chemistry, University of Science \& Technology, Bannu 28100, Khyber Pakhtunkhwa, Pakistan \\ ${ }^{2}$ Department of Chemistry, Kohat University of Science \& Technology (KUST), Kohat 26000, Khyber Pakhtunkhwa, Pakistan
}

Correspondence should be addressed to Afzal Shah; afzalnm@yahoo.com

Received 31 May 2013; Revised 16 August 2013; Accepted 17 August 2013

Academic Editor: Somdet Srichairatanakool

Copyright (C) 2013 Afzal Shah et al. This is an open access article distributed under the Creative Commons Attribution License, which permits unrestricted use, distribution, and reproduction in any medium, provided the original work is properly cited.

\begin{abstract}
Essential and nonessential heavy metals like iron (Fe), nickel (Ni), manganese (Mn), zinc (Zn), copper $(\mathrm{Cu})$, cadmium $(\mathrm{Cd})$, chromium $(\mathrm{Cr})$, and lead $(\mathrm{Pb})$ were analyzed in four selected medicinal plants such as Capparis spinosa, Peganum harmala, Rhazya stricta, and Tamarix articulata by flame atomic absorption spectrophotometer (FAAS). These medicinal plants are extensively used as traditional medicine for treatment of various ailments by local physicians in the area from where these plants were collected. The concentration level of heavy metals in the selected plants was found in the decreasing order as $\mathrm{Fe}>\mathrm{Zn}>\mathrm{Mn}>\mathrm{Cu}>\mathrm{Ni}>\mathrm{Cr}>\mathrm{Cd}>$ $\mathrm{Pb}$. The results revealed that the selected medicinal plants accumulate these elements at different concentrations. Monitoring such medicinal plants for heavy metals concentration is of great importance for physicians, health planners, health care professionals, and policymakers in protecting the public from the adverse effects of these heavy metals.
\end{abstract}

\section{Introduction}

Medicinal plants are commonly used in a large number of medicines. They have worldwide applications in the treatment of different types of diseases. According to the survey reported by World Health Organization (WHO), about $80 \%$ of the world's population consumes indigenous medicinal plants in direct and indirect ways to treat their diseases. Due to limited medical facilities in the rural areas of the developing countries including Pakistan, many medicinal plants are traditionally used for the treatment of diseases like skin infections, diarrhea, diabetes, malaria, respiratory problems, and fungal and bacterial infections [1]. Pakistan being a developing country has insufficient medical setup in its rural areas. Thus, people of these areas depend on preused medicines prepared from different medicinal plants [2]. The mankind uses different medicinal plants in many respects, as a food for nutritional purpose, medicine for treatment of infections, and constituent of cosmetics for maintenance of healthy skin. These plants have significant role in the regulation of various body systems. The nutritious value as well as the toxicity of the medicinal plants is due to their chemical composition.
The trace heavy metals like $\mathrm{Fe}, \mathrm{Cu}, \mathrm{Zn}, \mathrm{Cu}, \mathrm{Mn}$, and $\mathrm{Ni}$ are essential nutrients but they become harmful and toxic when their concentration exceeds the recommended standards. Lead and cadmium are nonessential heavy metals. They are extremely toxic even in very minute amounts [3].

The purpose of the current study was to quantify heavy metals concentration in some important medicinal plants. The subject plants are thoroughly consumed by the general public and it is the utmost need of the day to explore the chemical compositions of these plants and make known their impact on public health. The undertaken studies will facilitate physician, health care professional, planners, technicians, and general public to use these plants in a significant manner.

\section{Materials and Methods}

2.1. Chemicals and Reagents. Analytical grade chemicals were purchased from Sigma-Aldrich Company. 65\% nitric acid $\left(\mathrm{HNO}_{3}\right), 30 \%$ hydrogen peroxide $\left(\mathrm{H}_{2} \mathrm{O}_{2}\right)$, and $70 \%$ perchloric acid $\left(\mathrm{HClO}_{4}\right)$ were used for digestion purpose, while multielement standard solution was used as a reference material. 
2.2. Instrument and Apparatuses. Flam atomic absorption spectrophotometer model Perkin Elmer 400 was used for analyzing the aforementioned heavy metals. All glasswares were soaked in $3 \mathrm{M} \mathrm{HNO}_{3}$ for the whole night, washed with deionized water, and rinsed with double distilled water to minimize the chances of interferences.

2.3. Sample Collection. Samples of the aforementioned medicinal plants and the respective soils were collected from two different sampling points, that is, polluted area (spot-1) and unpolluted area (spot-2) of District Karak, Khyber Pakhtunkhwa, Pakistan.

2.4. Samples Treatment. All parts especially the roots of the plants were washed with fresh running water to remove dirt, dust, and other contaminated agents. Furthermore, the plant samples were washed with deionized water for more cleaning. The plants samples were dried in a shade at room temperature $\left(22-25^{\circ} \mathrm{C}\right)$. The dried plant parts were crushed, powdered and homogenized using an agate mortar and pestle. The powdered, samples were kept in polyethylene sampling bags separately for further processing. Soil samples were collected from the surrounding areas of plants' roots at about 8-10 cm depth. The soil samples were also dried, powdered, and placed in the polyethylene sampling bags.

2.5. Samples Digestion. A homogeneous solution of $\mathrm{HNO}_{3}$ and $\mathrm{H}_{2} \mathrm{O}_{2}$ in $2: 1$ strength was prepared. Dried, powdered, and $1 \mathrm{~g}$ preweighed quantity of different parts of each plant was dissolved in this solution. To increase the solubility, the sample solution was heated on hot plate at $130^{\circ} \mathrm{C}$ until the volume was reduced to $3 \mathrm{~mL}$. Then, the solution was cooled and filtered into $25 \mathrm{~mL}$ volumetric flask using Whatman 42 filter paper. The filtrate was diluted up to the mark [4]. The finally powdered and $1 \mathrm{~g}$ preweighed each soil sample was dissolved in $10 \mathrm{~mL} \mathrm{HNO}_{3}$ and kept for 24 hrs. Then, $5 \mathrm{~mL}$ of $\mathrm{HClO}_{4}$ was added to the soil sample solution. The whole mixture was heated until the volume was reduced to $3 \mathrm{~mL}$. Then, the sample solution was cooled and filtered into a $25 \mathrm{~mL}$ volumetric flask and diluted up to the mark [5].

2.6. Methodology. All the sample solutions were analyzed by FAAS using nitrous oxide $\left(\mathrm{N}_{2} \mathrm{O}\right)$-acetylene flame. About $2700^{\circ} \mathrm{C}$ temperature was produced in the ignition chamber and provided enhanced reducing settings for the atomization of the respective heavy metal. Each sample solution was aspirated by nebulizer, converted into an aerosol, mixed with the gases of flame, and conditioned into atomic form. Only a small portion, about $5 \%$ of the total sample, was allowed to aspirate which significantly controlled interferences. All the sample solutions were analyzed for the estimation of trace heavy metals like $\mathrm{Fe}, \mathrm{Ni}, \mathrm{Mn}, \mathrm{Zn}, \mathrm{Cu}, \mathrm{Cd}, \mathrm{Cr}$, and $\mathrm{Pb}$.

\section{Results and Discussions}

The results obtained during the undertaken studies are appended in Tables 1 and 2. It was found that the wet-digestion method is more significant than the already reported dry-digestion method [6]. The average metals contents in
Average metals concentration in MPSS \& SSS

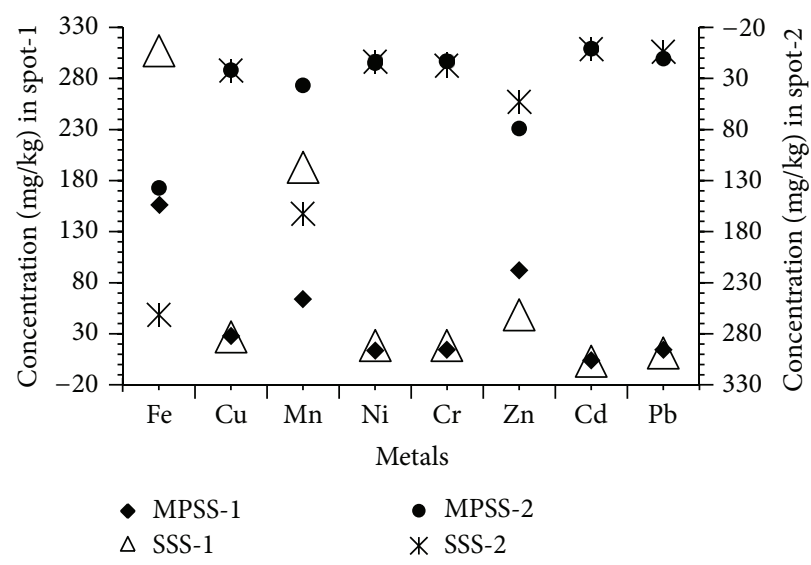

FIgURE 1: Average metals contents in medicinal plants and soil sample. MPSS: medicinal plants samples of spot: SSS: soil samples of spot.

medicinal plants and soil samples were not in linear fashion as evident from Figure 1. It was observed that the chemical composition of medicinal plants and soil samples was highly different in every segment of the undertaken studies.

3.1. Iron Determination. It is the most abundant and an essential constituent for all plants and animals. On the other hand, at high concentration, it causes tissues damage and some other diseases in humans. It is also responsible for anemia and neurodegenerative conditions in human being [7]. The results indicate that soil samples of both spots (I and II) contained Fe concentration between the range of 235.53 and $341.90 \mathrm{mg} / \mathrm{kg}$. The soil of Peganum harmala of spot-1 had the highest contents $(341.90 \mathrm{mg} / \mathrm{kg})$, while the soil of Rhazya stricta of spot2 contained the least level $(235.53 \mathrm{mg} / \mathrm{kg})$ of Fe. Among the plant parts, the concentration of Fe varied between 33.77 and $79.60 \mathrm{mg} / \mathrm{kg}$. The highest concentration of Fe $(79.60 \mathrm{mg} / \mathrm{kg})$ was found in the roots of Peganum harmala of spot-1, and the Rhazya stricta stem of spot-2 had the least amount of Fe $(33.77 \mathrm{mg} / \mathrm{kg}$ ) (Table 2). The high concentrations of Fe in the roots of plant formulate two hypotheses: (i) it may be due to higher absorption capacity of plant's roots, or (ii) it may be due to the presence of higher amounts of iron in the respective soil. It means that C. spinosa plants have the high ability to absorb the metals from the soil. The WHO recommended level of iron in medicinal plants is $20 \mathrm{mg} / \mathrm{kg}$, while its dietary intake is $10-28 \mathrm{mg} /$ day [8].

3.2. Chromium Determination. It plays a vital role in the metabolism of cholesterol, fat, and glucose. Its deficiency causes hyperglycemia, elevated body fat, and decreased sperm count, while at high concentration it is toxic and carcinogenic [9]. The $\mathrm{Cr}$ contents in the soil samples were found between the range of 2.63 and $32.53 \mathrm{mg} / \mathrm{kg}$. The highest and lowest contents of Cr occurred in the soils of spot-1 and spot-2 of Rhazya stricta, respectively. In plant parts, the concentration of Cr occurred between the range of 0.17 and $9.61 \mathrm{mg} / \mathrm{kg}$. The leaves of Rhazya stricta of spot-1 contained the maximum 
TABLE 1: Level of heavy metals $(\mathrm{mg} / \mathrm{kg})$ in medicinal plants and soil samples of spot-1.

\begin{tabular}{lccccccccc}
\hline Plant Name & Sample & $\mathrm{Fe}$ & $\mathrm{Cu}$ & $\mathrm{Mn}$ & $\mathrm{Ni}$ & $\mathrm{Cr}$ & $\mathrm{Zn}$ & $\mathrm{Cd}$ & $\mathrm{Pb}$ \\
\hline \multirow{5}{*}{ Capparis spinosa } & Soil & $274.37 \pm 0.11$ & $6.04 \pm 0.22$ & $134.79 \pm 0.01$ & $5.27 \pm 0.01$ & $3.07 \pm 0.02$ & $17.81 \pm 0.23$ & $0.15 \pm 0.09$ & $16.57 \pm 0.11$ \\
& Leaves & $50.30 \pm 0.01$ & $15.41 \pm 0.07$ & $8.07 \pm 0.01$ & $1.68 \pm 0.05$ & $1.23 \pm 0.01$ & $26.73 \pm 0.13$ & $0.10 \pm 0.07$ & $4.75 \pm 0.01$ \\
& Stem & $35.80 \pm 0.21$ & $6.20 \pm 0.06$ & $22.02 \pm 0.16$ & $0.70 \pm 0.05$ & $2.70 \pm 0.01$ & $26.08 \pm 0.11$ & $\mathrm{BDL}$ & $5.41 \pm 0.06$ \\
& Root & $38.69 \pm 0.04$ & $4.93 \pm 0.01$ & $23.21 \pm 0.01$ & $0.81 \pm 0.16$ & $3.00 \pm 0.02$ & $10.59 \pm 0.02$ & $0.05 \pm 0.01$ & $5.42 \pm 0.08$ \\
\hline \multirow{5}{*}{ Peganum harmala } & Soil & $341.90 \pm 0.07$ & $71.89 \pm 0.03$ & $159.91 \pm 0.03$ & $22.74 \pm 0.12$ & $4.04 \pm 0.01$ & $69.35 \pm 0.29$ & $0.45 \pm 0.01$ & $12.00 \pm 0.05$ \\
& Leaves & $48.11 \pm 0.03$ & $7.94 \pm 0.20$ & $18.65 \pm 0.03$ & $1.99 \pm 0.04$ & $1.00 \pm 0.15$ & $21.99 \pm 0.05$ & $0.09 \pm 0.04$ & $4.97 \pm 0.02$ \\
& Stem & $53.07 \pm 0.01$ & $8.39 \pm 0.07$ & $21.99 \pm 0.09$ & $2.00 \pm 0.03$ & $1.96 \pm 0.13$ & $30.76 \pm 0.14$ & $0.15 \pm 0.05$ & $5.14 \pm 0.01$ \\
& Root & $56.87 \pm 0.03$ & $17.67 \pm 0.02$ & $84.73 \pm 0.09$ & $6.23 \pm 0.15$ & $2.89 \pm 0.11$ & $71.08 \pm 0.50$ & $0.19 \pm 0.02$ & $9.68 \pm 0.07$ \\
\hline \multirow{5}{*}{ Rhazya stricta } & Soil & $285.34 \pm 0.04$ & $12.52 \pm 0.12$ & $229.56 \pm 0.06$ & $21.99 \pm 0.04$ & $32.53 \pm 0.05$ & $50.99 \pm 0.30$ & $1.99 \pm 0.90$ & $8.00 \pm 0.04$ \\
& Leaves & $51.38 \pm 0.01$ & $9.98 \pm 0.06$ & $12.75 \pm 0.03$ & $5.86 \pm 0.02$ & $9.61 \pm 0.07$ & $32.72 \pm 0.01$ & $1.26 \pm 0.00$ & $2.91 \pm 0.01$ \\
& Stem & $43.62 \pm 0.23$ & $6.85 \pm 0.01$ & $11.87 \pm 0.13$ & $5.04 \pm 0.07$ & $7.96 \pm 0.01$ & $27.81 \pm 0.16$ & $1.12 \pm 0.00$ & $2.73 \pm 0.01$ \\
& Root & $74.93 \pm 0.17$ & $10.78 \pm 0.02$ & $13.63 \pm 0.02$ & $6.21 \pm 0.01$ & $9.08 \pm 0.04$ & $33.77 \pm 0.05$ & $1.93 \pm 0.04$ & $4.76 \pm 0.07$ \\
\hline \multirow{6}{*}{ Tamarix articulate } & Leaves & $42.05 \pm 0.03$ & $5.74 \pm 0.03$ & $10.11 \pm 0.02$ & $7.00 \pm 0.05$ & $5.69 \pm 0.02$ & $22.03 \pm 0.18$ & $0.03 \pm 0.02$ & $1.82 \pm 0.04$ \\
& Stem & $53.00 \pm 0.15$ & $8.01 \pm 0.03$ & $12.07 \pm 0.01$ & $10.21 \pm 0.06$ & $7.37 \pm 0.03$ & $30.41 \pm 0.08$ & $1.09 \pm 0.01$ & $2.61 \pm 0.13$ \\
& Root & $79.6 \pm 0.11$ & $5.64 \pm 0.08$ & $15.88 \pm 0.01$ & $11.59 \pm 0.02$ & $4.22 \pm 0.02$ & $34.75 \pm 0.03$ & $1.58 \pm 0.02$ & $3.99 \pm 0.03$ \\
\hline
\end{tabular}

Values are mean \pm standard deviation, BDL: below detection limit.

TABLE 2: Level of heavy metals $(\mathrm{mg} / \mathrm{kg})$ in medicinal plants and soil samples of spot-2.

\begin{tabular}{lccccccccc}
\hline Plant Name & Sample & $\mathrm{Fe}$ & $\mathrm{Cu}$ & $\mathrm{Mn}$ & $\mathrm{Ni}$ & $\mathrm{Cr}$ & $\mathrm{Zn}$ & $\mathrm{Cd}$ & $\mathrm{Pb}$ \\
\hline \multirow{5}{*}{ Capparis spinosa } & Soil & $282.25 \pm 0.09$ & $7.58 \pm 0.13$ & $111.04 \pm 0.08$ & $3.90 \pm 0.17$ & $2.63 \pm 0.03$ & $18.70 \pm 0.22$ & $0.25 \pm 0.01$ & $8.32 \pm 0.09$ \\
& Leaves & $49.94 \pm 0.01$ & $6.39 \pm 0.06$ & $12.03 \pm 0.03$ & $0.88 \pm 0.02$ & $2.19 \pm 0.07$ & $26.87 \pm 0.10$ & $0.07 \pm 0.00$ & $5.03 \pm 0.01$ \\
& Stem & $40.50 \pm 0.23$ & $5.72 \pm 0.01$ & $3.15 \pm 0.13$ & $1.01 \pm 0.07$ & $2.44 \pm 0.01$ & $16.47 \pm 0.16$ & $0.07 \pm 0.00$ & $5.67 \pm 0.01$ \\
& Root & $51.15 \pm 0.17$ & $1.84 \pm 0.02$ & $7.96 \pm 0.02$ & $0.82 \pm 0.10$ & $0.17 \pm 0.04$ & $8.37 \pm 0.05$ & $\mathrm{BDL}$ & $2.54 \pm 0.07$ \\
\hline \multirow{5}{*}{ Peganum harmala } & Soil & $245.99 \pm 0.06$ & $57.00 \pm 0.01$ & $139.79 \pm 0.04$ & $7.87 \pm 0.01$ & $3.74 \pm 0.04$ & $93.19 \pm 0.11$ & $0.23 \pm 0.00$ & $6.99 \pm 0.09$ \\
& Leaves & $34.07 \pm 0.03$ & $7.12 \pm 0.03$ & $15.01 \pm 0.02$ & $1.00 \pm 0.05$ & $0.26 \pm 0.02$ & $25.73 \pm 0.18$ & $0.03 \pm 0.00$ & $3.87 \pm 0.04$ \\
& Stem & $38.99 \pm 0.15$ & $11.11 \pm 0.03$ & $21.10 \pm 0.01$ & $1.24 \pm 0.06$ & $0.84 \pm 0.03$ & $20.06 \pm 0.08$ & $0.05 \pm 0.01$ & $3.00 \pm 0.13$ \\
& Root & $51.89 \pm 0.11$ & $11.55 \pm 0.08$ & $22.99 \pm 0.01$ & $2.41 \pm 0.02$ & $3.01 \pm 0.02$ & $47.71 \pm 0.03$ & $0.09 \pm 0.00$ & $6.04 \pm 0.03$ \\
\hline \multirow{5}{*}{ Rhazya stricta } & Soil & $235.53 \pm 0.03$ & $10.03 \pm 0.09$ & $218.36 \pm 0.03$ & $20.00 \pm 0.06$ & $29.18 \pm 0.06$ & $47.64 \pm 0.00$ & $1.89 \pm 0.02$ & $6.16 \pm 0.01$ \\
& Leaves & $37.54 \pm 0.01$ & $7.31 \pm 0.03$ & $9.92 \pm 0.03$ & $5.99 \pm 0.01$ & $8.37 \pm 0.02$ & $26.89 \pm 0.08$ & $1.15 \pm 0.01$ & $3.00 \pm 0.04$ \\
& Stem & $33.77 \pm 0.02$ & $6.47 \pm 0.02$ & $9.71 \pm 0.02$ & $4.64 \pm 0.07$ & $7.72 \pm 0.03$ & $24.00 \pm 0.02$ & $1.36 \pm 0.00$ & $2.11 \pm 0.03$ \\
& Root & $39.33 \pm 0.03$ & $9.83 \pm 0.01$ & $8.74 \pm 0.01$ & $5.09 \pm 0.01$ & $8.15 \pm 0.21$ & $28.79 \pm 0.04$ & $1.48 \pm 0.00$ & $4.02 \pm 0.01$ \\
\hline \multirow{6}{*}{ Tamarix articulata } & Leaves & $36.42 \pm 0.05$ & $4.98 \pm 0.06$ & $10.00 \pm 0.06$ & $6.59 \pm 0.05$ & $5.19 \pm 0.05$ & $27.00 \pm 0.01$ & $0.08 \pm 0.01$ & $1.09 \pm 0.04$ \\
& Stem & $63.01 \pm 0.01$ & $7.00 \pm 0.03$ & $10.71 \pm 0.03$ & $9.00 \pm 0.01$ & $7.09 \pm 0.01$ & $29.38 \pm 0.02$ & $0.12 \pm 0.00$ & $2.10 \pm 0.03$ \\
& Root & $72.87 \pm 0.02$ & $9.51 \pm 0.03$ & $15.24 \pm 0.03$ & $14.73 \pm 0.02$ & $7.83 \pm 0.02$ & $32.58 \pm 0.05$ & $1.06 \pm 0.01$ & $2.81 \pm 0.01$ \\
\hline
\end{tabular}

Values are mean \pm standard deviation, BDL: below detection limit.

amount $(9.61 \mathrm{mg} / \mathrm{kg})$ of $\mathrm{Cr}$, while the roots of Capparis spinosa of spot- 2 had the minimum amount $(0.179 \mathrm{mg} / \mathrm{kg})$ of $\mathrm{Cr}$. The high concentration of Cr occurred in the leaves of the Rhazya stricta of the polluted spot. It may be due to the absorption of Cr contents from the polluted air. Hence, Rhazya stricta plant may be helpful in the reduction of air pollution. WHO's permissible limit of chromium in medicinal plant is $1.5 \mathrm{mg} / \mathrm{kg}$, while its daily dietary intake is $0.2 \mathrm{mg}$ [8].

3.3. Zinc Determination. It is the basic component of a large number of different enzymes and plays structural, regulatory, and catalytic functions. It also has very important role in
DNA synthesis, normal growth, brain development, bone formation, and wound healing. At high level, Zinc is neurotoxin [10]. The soil of Peganum harmala of spot-2 had the highest contents $(93.19 \mathrm{mg} / \mathrm{kg})$ of $\mathrm{Zn}$, while the soil of Capparis spinosa of spot-1 had the least concentration $(17.81 \mathrm{mg} / \mathrm{kg})$ of $\mathrm{Zn}$. Among the plant parts $\mathrm{Zn}$ concentration, occurred in the range of $8.37-71.08 \mathrm{mg} / \mathrm{kg}$. The highest concentration of Zn $(71.08 \mathrm{mg} / \mathrm{kg})$ occurred in the roots of Peganum harmala Linn of spot-1, and the roots of Capparis spinosa of spot-2 contained the least contents $(8.37 \mathrm{mg} / \mathrm{kg})$ of Zinc. The high concentration of $\mathrm{Zn}$ in the roots of the Peganum harmala growing in polluted areas may be due to the absorption of the 
metals from the polluted soils. WHO's recommended limit of zinc in medicinal plant is $50 \mathrm{mg} / \mathrm{kg}$, while its intake in food is $11 \mathrm{mg} /$ day [4].

3.4. Manganese Determination. It is a very essential trace heavy metal for plants and animals growth. Its deficiency produces severe skeletal and reproductive abnormalities in mammals. High concentration of Mn causes hazardous effects on lungs and brains of humans [11]. The soil of Tamarix articulata of spot-1 contained the highest level $(247.62 \mathrm{mg} / \mathrm{kg})$ of $\mathrm{Mn}$, while the Capparis spinosa soil of spot-2 contained the least level $(111.04 \mathrm{mg} / \mathrm{kg})$ of Mn. Among the plant parts, the Mn contents varied between the range of 3.1 to $84.73 \mathrm{mg} / \mathrm{kg}$. The Peganum harmala roots growing in spot-1 had the highest amount $(84.73 \mathrm{mg} / \mathrm{kg})$ of $\mathrm{Mn}$, and the Capparis spinosa stems growing in spot-2 contained the least contents $(3.15 \mathrm{mg} / \mathrm{kg})$ of Mn. Like Zn, manganese also occurred in high amount in the roots of Peganum harmala which support the idea that this plant has high absorption rate of trace heavy metals from the soil where it grows. WHO's maximum permissible limit of $\mathrm{Mn}$ in medicinal plants is $200 \mathrm{mg} / \mathrm{kg}$, while its daily intake is $11 \mathrm{mg}$ [8]. The polluted soils contained higher amounts of trace heavy metals. Thus, the plants get sufficient amount of these trace heavy metals from the soil where they grow. These plants can also be applied for soil pollution control to make the soil useful and safe for further cultivation of crops/vegetables in these soils.

3.5. Nickel Determination. It is also an essential element for plants and animals. In small quantity, nickel is necessary for the regulation of lipid contents in tissues and for the formation of red blood cells. But at high level, it becomes toxic and causes severe diseases like loss of body weight, loss of vision, and heart and liver failures, as well as skin irritation [12]. The experimental data revealed that $\mathrm{Ni}$ concentration in soil samples occurred in a range of $3.90-23.53 \mathrm{mg} / \mathrm{kg}$. The Tamarix articulata soil of spot-1 had the highest level $(23.53 \mathrm{mg} / \mathrm{kg})$, while the Capparis spinosa soil of spot- 2 had the least contents $(3.90 \mathrm{mg} / \mathrm{kg})$ of Ni. Among the plant parts, Ni concentration was found in the range of $0.70-14.73 \mathrm{mg} / \mathrm{kg}$. The roots of Tamarix articulata of spot- 2 had the highest concentration $(14.73 \mathrm{mg} / \mathrm{kg})$ of Ni and the stem of Capparis spinosa of spot-1 had the least level $(0.70 \mathrm{mg} / \mathrm{kg})$ of Ni. The high concentration of Ni present in the roots of Tamarix articulata indicate that the plant absorbs this trace heavy metals from the respective soil. WHO's permissible limit of nickel in medicinal plant is $1.5 \mathrm{mg} / \mathrm{kg}$, while its routine requirement for mankind is $1 \mathrm{mg} /$ day [13].

3.6. Copper Determination. Being an essential trace element, it is necessary for many enzymes. It is needed for the normal growth and development. High concentration of $\mathrm{Cu}$ causes metal fumes fever, hair and skin decolorations, dermatitis, respiratory tract diseases, and some other fatal diseases in human beings [4]. Copper content was determined in all parts of each medicinal plant and its soil. All the tested samples contained the significant amount of $\mathrm{Cu}$. The highest level $(71.89 \mathrm{mg} / \mathrm{kg})$ of Cu was found in the soil of Peganum harmala of spot-1, and the soil of Capparis spinosa of spot-1 had the least level $(6.04 \mathrm{mg} / \mathrm{kg})$ of $\mathrm{Cu}$. In plant parts, $\mathrm{Cu}$ concentration occurred in a range of $1.84-17.67 \mathrm{mg} / \mathrm{kg}$. The Peganum harmala roots of spot-1 had the highest contents $(17.67 \mathrm{mg} /$ $\mathrm{kg}$ ), while the Capparis spinosa roots of spot-2 contained the least concentration $(1.84 \mathrm{mg} / \mathrm{kg})$ of $\mathrm{Cu}$. The high concentration of $\mathrm{Cu}$ and the other trace heavy metals present in the underground parts of the plants may be due to the absorption ability of the plants to get the trace heavy metals from the polluted soils. WHO's permissible limit of copper in medicinal plants is $10 \mathrm{mg} / \mathrm{kg}$, while its intake in food is 2$3 \mathrm{mg} /$ day [13].

3.7. Lead Determination. It is a non essential heavy metal. $\mathrm{Pb}$ causes oxidative stress and contributes to the pathogenesis of lead poisoning by disrupting the delicate antioxidant balance of the mammalian cells. High level accumulation of $\mathrm{Pb}$ in body causes anemia, colic, headache, brain damage, and central nervous system disorder [14]. The soil samples contained the $\mathrm{Pb}$ concentration in a range of $2.08-16.57 \mathrm{mg} / \mathrm{kg}$. The soil of Capparis Spinosa of spot-1 had the highest level $(16.57 \mathrm{mg} / \mathrm{kg})$ of $\mathrm{Pb}$, while the soil of Tamarix articulata of spot-2 had the least level $(2.08 \mathrm{mg} / \mathrm{kg})$ of $\mathrm{Pb}$. Among the different parts of plants, the $\mathrm{Pb}$ concentration varied between the range of 1.09 and $9.68 \mathrm{mg} / \mathrm{kg}$. The roots of Peganum harmala of spot- 1 contained the highest level $(9.68 \mathrm{mg} / \mathrm{kg})$ of $\mathrm{Pb}$, and the leaves of Tamarix articulata of spot- 2 had the least level $(1.09 \mathrm{mg} / \mathrm{kg})$ of $\mathrm{Pb}$. WHO's permissible limit of lead in medicinal plant is $10 \mathrm{mg} / \mathrm{kg}$ [8].

3.8. Cadmium Determination. It is also a non essential heavy metal. It is extremely toxic even at low concentration. It causes learning disabilities and hyperactivity in children [15]. The experimental results showed that $\mathrm{Cd}$ concentration in soil samples occurred between the range of 0.15 and $1.99 \mathrm{mg} / \mathrm{kg}$. The Rhazya stricta soil of spot-1 had the highest level $(1.99 \mathrm{mg} / \mathrm{kg})$ while the Capparis spinosa soil of spot-1 had the least contents $(0.15 \mathrm{mg} / \mathrm{kg})$ of Cd. Among the plant parts, the $\mathrm{Cd}$ concentration varied between the range of 0.03 and $1.93 \mathrm{mg} / \mathrm{kg}$. The roots of Rhazya Stricta of spot-1 contained the highest level of $\mathrm{Cd}$, while the leaves of Peganum harmala of spot- 2 had the least level of Cd. Being a non essential metal, it is considered very toxic. The WHO recommended level of cadmium in medicinal plants is $0.3 \mathrm{mg} / \mathrm{kg}$ [13].

\section{Conclusion}

The analyses show that soil samples collected from polluted areas have high concentrations of heavy metals than nonpolluted areas. It may be due to geological strata or pollution of the studied area. All plants absorb water and mineral from soil through the ascent of sap; as a result, the heavy metals uptake by these medicinal plants also occurs in the same way. After absorption, these heavy metals are accumulated in various parts of the medicinal plants and are entered into biological chain after ingestion of these medicinal plants by animals and mankind. For long periods, the medicinal plants are traditionally used by local people for treatment of various ailments and thus also ingest the subject heavy metals. Hence, in this way, the heavy metal toxicity occurs in mankind as 
a side effect instead of treatment. The assays of heavy metals varied from spot to spot, plant to plant, and also in different parts of each plant, depending upon the chemical composition of soil and absorption rate by plants. Thus, it is essentially required that every medicinal plant should be checked for contaminant load before processing it for further pharmaceutical purposes or for local human consumption.

\section{References}

[1] A. J. Pirzada, W. Shaikh, K. U. Ghani, and K. A. Laghari, "Uses of medicinal plants," Sindh University Research Journal, vol. 41, no. 2, pp. 220-222, 2009.

[2] S. M. Wazir, S. Saima, A. A. Dasti, and M. Subhan, "Ethnobotanical importance of salt range species of District Karak," Pakistan Journal of Plant Sciences, vol. 13, no. 1, pp. 29-31, 2007.

[3] I. Khan, J. Ali, and H. Tullah, "Heavy metals determination in medicinal plant Withania somnifera growing in various areas of peshawar, NWFP, Pakistan," Journal of the Chemical Society of Pakistan, vol. 30, no. 1, pp. 69-74, 2008.

[4] S. A. Khan, L. Khan, I. Hussain, K. B. Marwat, and N. Akhtar, "Profile of heavy metals in selected medicinal plants," Journal of Weed Sciences and Research, vol. 14, no. 1-2, pp. 101-110, 2008.

[5] M. Soylak, M. Tuzen, I. Narin, and H. Sari, "Comparison of microwave, dry and wet digestion procedures for the determination of trace metal contents in spice samples produced in Turkey," Journal of Food and Drug Analysis, vol. 12, no. 3, pp. 254-258, 2004.

[6] A. Niaz, N. Ullah, A. Rehman, I. Ahmad, M. Ikhlaq, and H. U. Rehman, "Pollution based study of heavy metals in some selected medicinal plants by dry digestion method," International Journal of Pharma Sciences and Research, vol. 4, no. 2, pp. 17-24, 2013.

[7] L. Fuortes and D. Schenck, "Marked elevation of urinary zinc levels and pleural-friction rub in metal fume fever," Veterinary and Human Toxicology, vol. 42, no. 3, pp. 164-165, 2000.

[8] World Health Organization, Quality Control Methods for Medicinal Plant Materials, WHO, Geneva, Switzerland, 1998.

[9] K. A. Chishti, F. A. Khan, S. S. M. Hassan et al., "Estimation of heavy metals in the seeds of blue and whitecapitulum's of silybum marianum grown in various districts of Pakistan," Journal of Basic and Applied Science, vol. 7, no. 1, pp. 45-49, 2011.

[10] B. A. Adelekan and K. D. Abegunde, "Heavy metals contamination of soil and groundwater at automobile mechanic villages in Ibadan, Nigeria," International Journal of Physical Sciences, vol. 6, no. 5, pp. 1045-1058, 2011.

[11] L. Järup, "Hazards of heavy metal contamination," British Medical Bulletin, vol. 68, pp. 167-182, 2003.

[12] S. P. McGrath and S. Smith, "Chromium and nickel," in Heavy Metals in Soils, B. J. Alloway, Ed., pp. 125-146, Blackie, Glasgow, UK, 1990.

[13] World Health Organization, Quality Control Methods for Medicinal Plant Materials, WHO, Geneva, Switzerland, 2005.

[14] A. Rehman, H. Ullah, R. U. Khan, and I. Ahmad, "Population based study of heavy metals in medicinal plant Capparis decidua," International Journal of Pharmacy and Pharmaceutical Sciences, vol. 5, no. 1, pp. 108-113, 2013.

[15] J. R. Hunt, "Bioavailability of iron, zinc, and other trace minerals from vegetarian diets," American Journal of Clinical Nutrition, vol. 78, no. 3, pp. 6335-6395, 2003. 

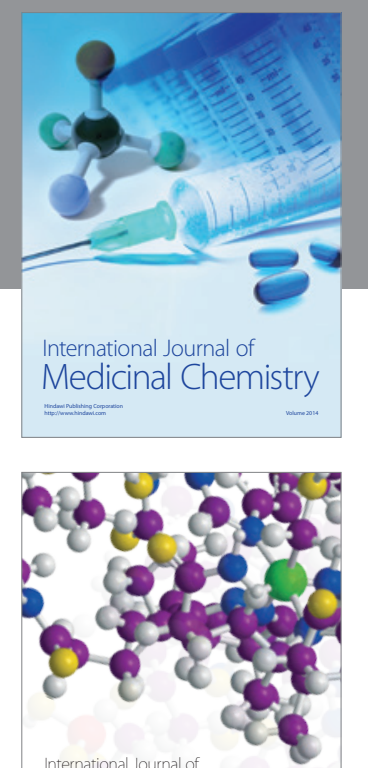

\section{Carbohydrate} Chemistry

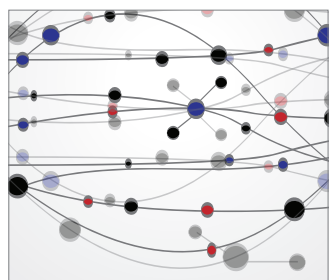

The Scientific World Journal
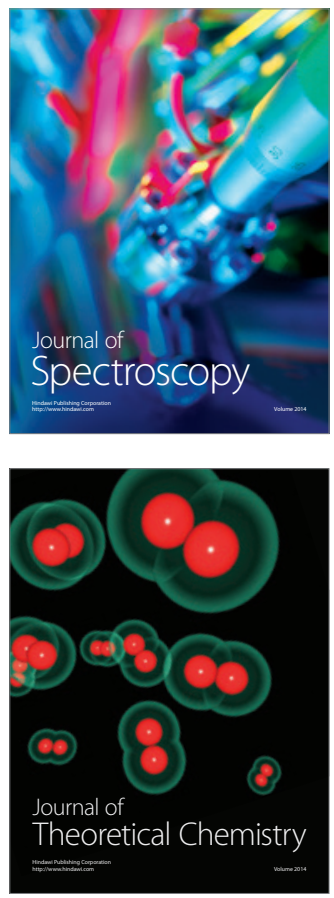
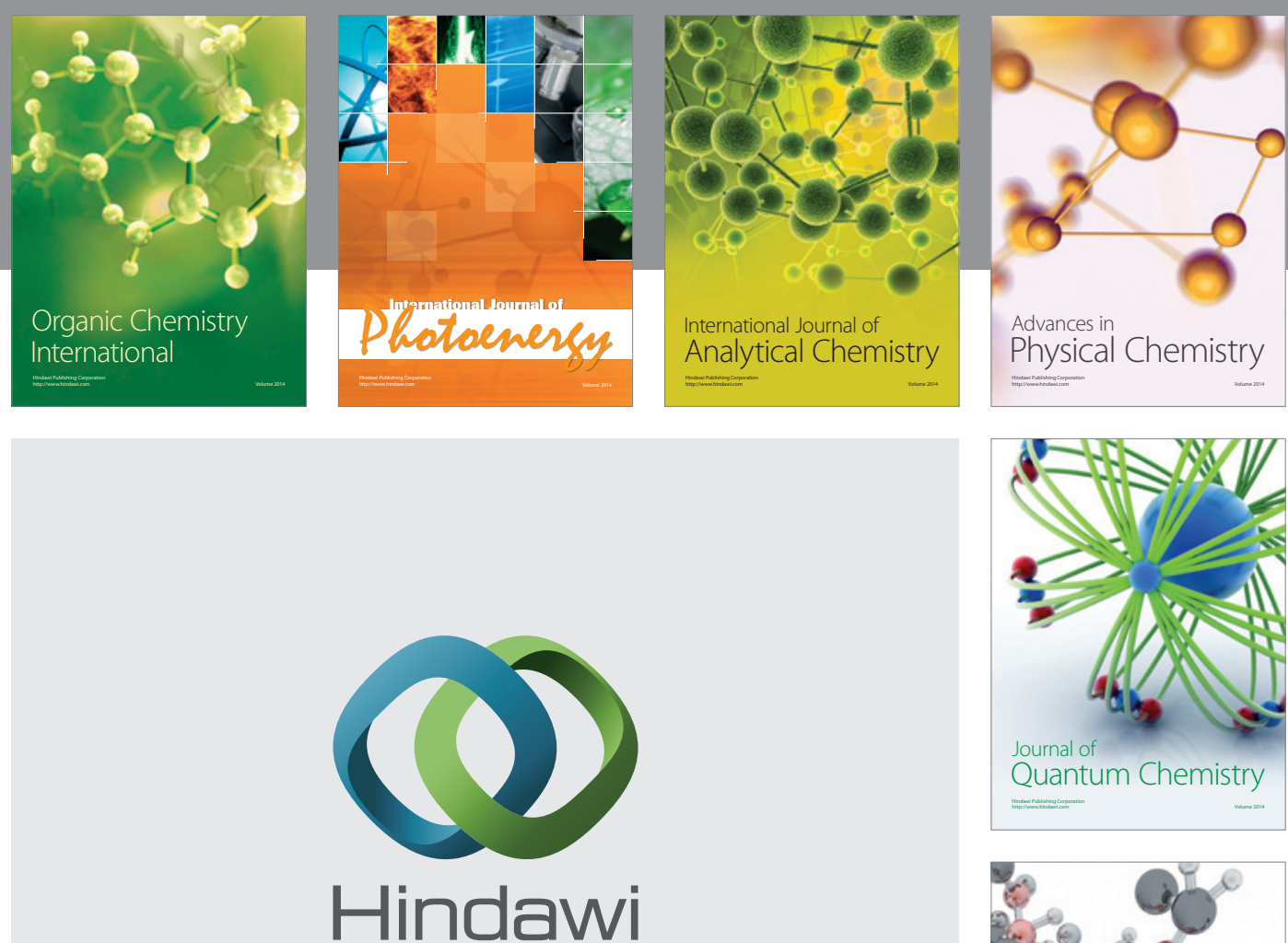

Submit your manuscripts at

http://www.hindawi.com

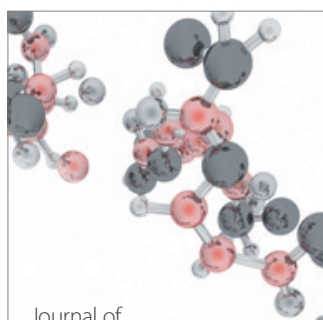

Analytical Methods

in Chemistry

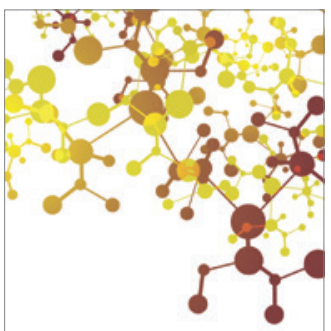

Journal of

Applied Chemistry

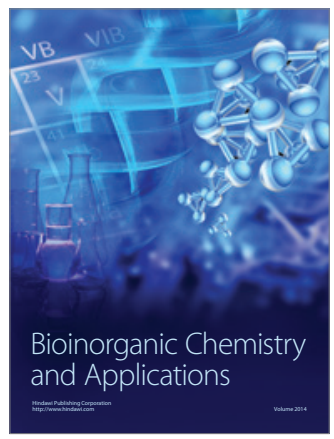

Inorganic Chemistry
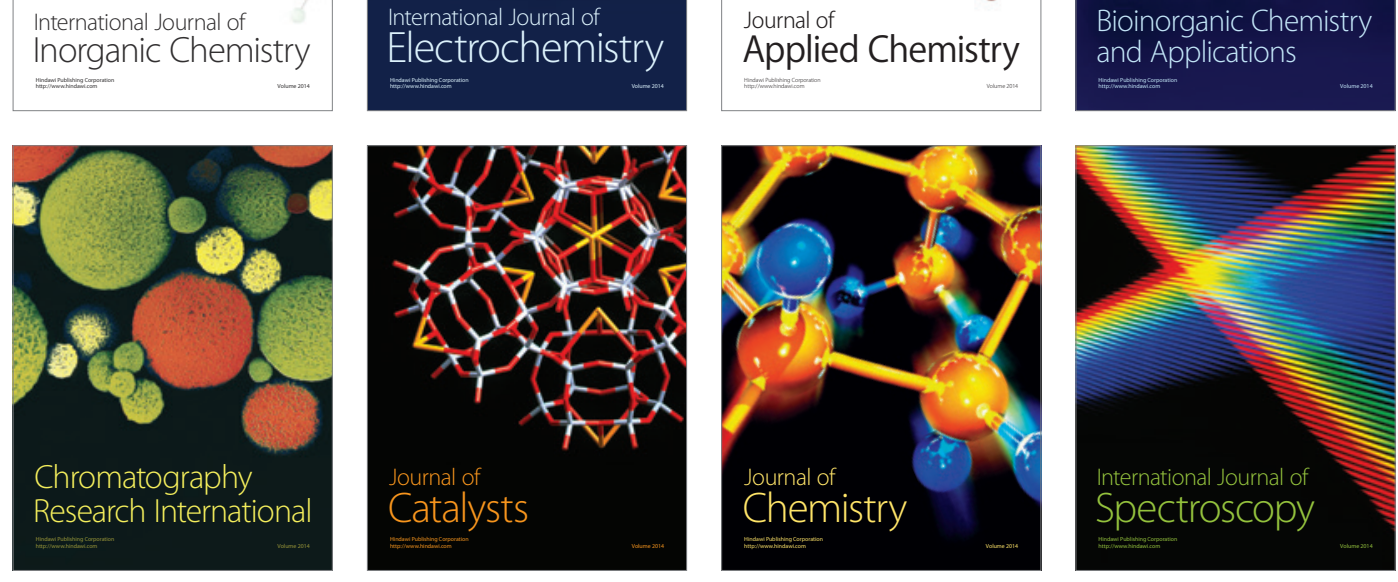